\title{
Diurnal variability of rainfall in Southwest Amazonia during the LBA-TRMM field campaign of the Austral summer of 1999.
}

\author{
José A. MARENGO푸 Gilberto FISCH²; Carlos MORALES ${ }^{3}$; Iria VENDRAME²; Paulo C. DIAS ${ }^{2}$
}

\begin{abstract}
The TRMM-LBA field campaign was held during the austral summer of 1999 in southwestern Amazonia. Among the major objectives, was the identification and description of the diurnal variability of rainfall in the region, associated with the different rain producing weather systems that occurred during the January-February season. By using a network of 40 digital rain gauges implemented in the state of Rondônia, and together with observations and analyses of circulation and convection, it was possible to identify details of the diurnal cycle of rainfall and the associated rainfall mechanisms.

Rainfall episodes were characterized by regimes of "low-level easterly" and "westerly" winds in the context of the largescale circulation. The westerly regime is related to an enhanced South Atlantic Convergence Zone (SACZ) and an intense and/or wide Low Level Jet (LLJ) east of the Andes, which can extend eastward towards Rondônia, even though some westerly regime episodes also show a LLJ that remains close to the foothill of the Andes. The easterly regime is related to easterly propagating systems (e.g. squall-lines) with possible weakened or less frequent LLJs and a suppressed SACZ.

Diurnal variability of rainfall during westerly surface wind regime shows a characteristic maximum at late afternoon followed by a relatively weaker second maximum at early evening (2100 Local Standard Time LST). The easterly regime composite shows an early morning maximum followed by an even stronger maximum in the afternoon.
\end{abstract}

\section{KEY WORDS}

Amazonia, convection, raingauge, rainfall, diurnal cycle

\section{Variação diurna da chuva no Sudoeste da Amazônia durante a campanba de campo do experimento LBA-TRMM no verão austral de 1999.}

\begin{abstract}
RESUMO
O experimento de campo do TRMM-LBA ocorreu conteceu durante o verão austral de 1999, na região do sudeste de Amazonia. Entre os principais objetivos deste trabalbo pode-se citar a identificação e descrição da variabilidade diurna da chuva nesta região, associada a diferentes fenômenos meteorológicos e sistemas de tempo que ocorreram durante o período de Janeiro-Fevereiro. Usando uma rede de 40 pluviômetros instalados no estado de Rondônia, ,juntamente com outras observações de circulação atmosférica e convecção, foi possível identificar detalhes do ciclo diurno de chuva e os mecanismos de circulação associados. Os eventos de chuva foram caracterizados por regimes de vento nos níveis baixos e no contexto da circulação de grande escala: ventos de oeste e de leste. O regime "de oeste" se associa a Zona de Convergência do Atlântico Sul (ZCAS) e a episódios intensos de jatos de baixos níveis ao leste dos Andes (LLJ), que podem estender seus efeitos até Rondônia. Episódios de eventos "de leste" se associam a sistemas meteorológicos que se propagam desde a Foz do Rio Amazonas em direção oeste (e.g. linhas de instabilidade) e podem ser acompanhados por episódios fracos de LLJ e de ZCAS. A variabilidade diurna de chuva durante episódios de circulação "de oeste" apresenta um máximo característico á tarde (1200-1400 hora local) com um máximo secundário á noite (2000-2200 hora local). O regime de circulação "de leste" mostra um máximo á tarde (1200-1400 hora local), precedido de um máximo secundário durante a madrugada (0000-0200 bora local).
\end{abstract}

PALAVRAS-CHAVE

Amazônia, convecção, chuva, pluviômetros, ciclo diurno

\footnotetext{
${ }^{1}$ Centro de Previsão de Tempo e Estudos Climáticos(CPTEC/INPE), Rodovia Dutra km. 40, 12630-000 Cachoeira Paulista, São Paulo, Brazil

${ }^{2}$ Centro Técnico Aeroespacial (CTA), São Jose dos Campos, São Paulo, Brazil

${ }^{3}$ Departamento de Ciências Atmosféricas, IAG, Universidade de São Paulo, São Paulo, Brazil
} 


\section{ACTA \\ AMAZONICA}

DIURNAL VARIABILITY OF RAINFALL IN SOUTHWEST AMAZONIA DURING THE LBA-TRMM FIELD CAMPAIGN OF THE AUSTRAL SUMMER OF 1999

\section{INTRODUCTION}

The Amazon River Basin displays strong diurnal variations in convective activity that are associated with variability in the near-surface circulation and rainfall, and these associations are more intense during the warm rainy season. In addition, stratiform precipitation is also present during rainy days determining variations in the timing of the daily maximum of rainfall if compared with convective precipitation. In the austral summer, the surface heating is greatest, as are the evaporation and evapotranspiration, producing unstable stratification and low level moisture needed to trigger convection.

The issues of diurnal variability of rainfall have been explored in previous studies using daily rainfall data in several parts of Amazonia as consequence of the ABRACOS (Anglo Brazilian Climate Observation Study) during 199094 (Gash and Nobre 1997) and previously using few isolated daily rainfall observations and satellite data (Marengo, 1995, Tota et al. 2000 among others). The lack of hourly rainfall observations across Amazônia makes comprehensive analyses of the diurnal and nocturnal precipitation cycle and its related near-surface circulation and convection features difficult. The strength of the diurnal cycle of precipitation in other tropical regions of Africa and tropical islands and areas bordering Amazonia suggests its importance for the Amazon River Basin.

The Large Scale Biosphere-Atmosphere Experiment in Amazonia-Wet Season Atmospheric Mesoscale Campaign (LBA WET-AMC) together with the Tropical Rainfall Mission Measurement (TRMM) satellite validation campaign in southern Amazonia provided a unique opportunity, in which surface and remote sensing observations were used to investigate the diurnal variability of convection, rainfall, and the hydrologic and energy cycles over Amazonia (Silva Dias et al. 2002). LBA is an international and multidisciplinary program intended to examine the effects of land use change on Amazonian and regional weather patterns. The combined mission was named as TRMM-LBA, and it was a major component of the NASA TRMM ground validation program and focused on the dynamical, microphysical, electrical and diabatic heating characteristics of tropical convection in Amazonia.

The launching of the TRMM satellite in November 1997 provides for quantitative measurements of tropical precipitation to be obtained on continuing basis over the entire global tropics. The so-called TRMM-LBA field validation campaign (Cifelli et al. 2002; Rickenbach et al. 2002) was conducted in parallel with the LBA-WET AMC, and among the observational network implemented for purposes of validation of the TRMM satellite, a special rain gauge network was deployed on networks on the state of Rondônia. The network of 40 rainfall stations was part of a substantial and well-defined ground validation program that was running in parallel with the space mission.

In the present study, we used hourly data from the TRMMLBA rain gauge network in Rondônia (Fig. 1) to investigate the diurnal cycle of rainfall under different rain producing mechanisms and synoptic regimes that affected the region during the January-February 1999 wet season. To accomplish this, we define the following objectives: a) To study the diurnal rainfall variability of rainfall using high frequency rainfall measurements, b) To discuss this variability in terms of local atmospheric phenomena such as organized local convection, and c) To discuss this diurnal variability linked to regional low-level circulation patterns that occurred during the LBAWET AMC field campaign. These circulation patterns identified as "westerly" and "easterly" low-level flow regimes are related to westward and eastward propagating weather systems that organize convection respectivelly. Comparisons are made with previous studies that used hourly rainfall information from the ABRACOS sites in northern, central and eastern Amazonia from the early 1990's (Gash and Nobre 1997; Liebmann et al. 1998), and some of the results derived from remote sensing data from the TRMM-LBA validation program (Rickenbach et al. 2002).

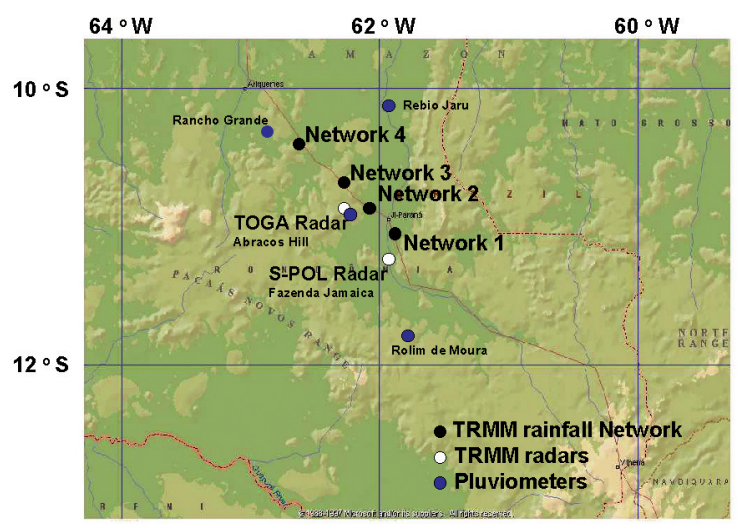

Figure 1 - Location of raingauge networks, rainfall sites, S-POL and TOGA radars and other LBA-WET AMC and TRMM-LBA instrumentation in the research site, in Rondônia, Southwest Amazonia.

\section{RAINFALL CLIMATOLOGY OF RONDÔNIA- SOUTHWEST AMAZONIA}

\section{Seasonal and interannual variability}

Annual rainfall in the Amazon River basin varies greatly. According to Figueroa \& Nobre (1990), Marengo (1992), Marengo \& Nobre (2001) and Liebmann \& Marengo (2001), three centers of abundant rainfall can be identified in Amazonia. One is located in Northwest Amazonia, with more than $3600 \mathrm{~mm}$ per year. Another region with abundant rainfall is the central part of Amazonia around $5{ }^{0} \mathrm{~S}$ with $2400 \mathrm{~mm}$ per year and with a dry season from June to November. A third center is found close to the mouth of the Amazon River near Belem, with more than $2800 \mathrm{~mm}$ 


\section{ACTA \\ AMAZONICA}

DIURNAL VARIABILITY OF RAINFALL IN SOUTHWEST AMAZONIA DURING THE LBA-TRMM FIELD CAMPAIGN OF THE AUSTRAL SUMMER OF 1999 per year. In northwestern Amazonia, the rainfall is abundant throughout the year reaching its maximum in April-June and with no dry season, while southern Amazonian's rain peaks earlier (January-March) and with a dry season in JuneAugust. The extreme high and localized values of precipitation in narrow strips along the eastern side of the Andean slopes are thought to be due to up glide condensation and a rain shadow effect on the lee side, so the localized maximum is due to the easterly winds being lifted when they flow toward the Andes. The coastal maximum is caused by nocturnal convergence between the trade wind and the land breeze.

Annual variation of rainfall is linked to annual changes in the large-scale upper-air circulation, and surface oceanic conditions have implicated the Atlantic, at least indirectly, as being responsible for interannual rainfall variability in the Amazon. Although the sun largely controls the timing in the annual cycle of rainfall, rainfall in different parts of the basin is triggered by different rain producing mechanisms (Garreaud \& Wallace, 1997; Fisch et al. 1998). These mechanisms can be grouped into the following categories:

- Diurnal deep convection resulting from surface warming, which is most prevalent in central Amazonia.

- Deep convection in northern Amazonia related to the Intertropical Convergence Zone (ITCZ) convection and the moisture transports from the Atlantic, this depends on the meridional Sea Surface Temperature (SST) gradient of the tropical Atlantic.

- Instability lines originating near the mouth of the Amazon River that move inland and may even reach the Andes can initiate rainfall in northern Amazonia.

- Convective activity at meso-scale and large-scale, associated with the penetration of frontal systems in the south/southeast Brazil that can reach western southern Amazonia.

In Rondônia, located on southwestern Amazonia, during austral summer, a southward migration of the near equatorial trough coupled with a southeastward retreat of the south Atlantic anticyclone result in increased moisture convergence and deep convection, and thus increased rainfall on the region. Synoptic features associated with rainfall in the region may consider the approaching mid latitude frontal incursions, the penetration of instability lines, the intensification of the South Atlantic Convergence Zone (SACZ), and the development and intensification of a northerly Low Level Jet east of the Andes LLJ (Nogues Paegle \& Mo, 1997, Marengo et al. 2002). Forcing of these systems can be originated via diurnal heating and/or interactions between propagating gravity waves/outflow boundaries emanating from convection originally located over elevated terrain (e.g., eastern slopes of the Andes) west of Rondônia earlier in the day.

\section{Diurnal variability}

There have been few studies based on observations of previous field experiments in some sections of Amazonia, and based on satellite derived convective indices and rainfall (Molion, 1987; Silva Dias et al. 1987; Arkin \& Meisner, 1987; Marengo, 1995; Garreaud \& Wallace, 1997; Liebmann et al. 1998; Imaoka \& Spencer, 2000; Lin et al. 2000; and Negri et al. 2000). Previous field experiments conducted in Amazonia such an Amazon Boundary Layer Experiment (ABLE) have observed significant variability in the diurnal cycle of rainfall. Diurnal cycle variability observed during ABLE was apparently a function of the dominant convective system type (Greco et al. 1990). Analyses of observed rainfall data by Gash et al. (1996) and Liebmann et al. (1998) based on the ABRACOS rainfall data indicate rainfall maximum around 1800-2200 Greenwich Meridian Time GMT (1400-1800 LST) at Ji-Paraná (Rondônia).

Studies by Imaoke \& Spencer (2000) and Lin et al. (2000) using TRMM data have shown variations in the diurnal cycle of rainfall across Amazonia, with maximum ( 2000 LST) over the central and southern parts of Amazonia, and afternoon maximum ( 1600 LST) over the central and northern parts. Lin and collaborators describe for Amazonia the diurnal cycle of convective rain with minimum $(1 \mathrm{~mm} / \mathrm{day})$ between 0900 and 1000 LST, and maximum ( $8 \mathrm{~mm} /$ day) between 1400 and 1600 LST. The observed stratiform precipitation over Amazonia shows a broad peak between 1200 and 1600 LST (suggesting a coexistence between abundant stratiform clouds with deep cumulus in the afternoon) and between 0000 and 0400 LST. Nesbitt et al. (2000) have identified for South America a strong afternoon response to daytime solar forcing, and using TRMM radar, ice scattering and lighting observations they show that these exhibit large frequencies near 1400-1600 LST, and diminish slowly throughout the local evening.

Ferreira da Costa et al. (1998) studied the diurnal rainfall variability in the ABRACOS sites (Gash et al. 1996) in forested and deforested areas nearby Ji-Paraná (Fig. 1) during 1992 to 1996 . Their study indicates that besides the fact of having more rainfall on forested areas compared to deforested areas (by about 28\%), the deforested area shows a maximum of rainfall concentrated between1300-1800 LST, while on the forested site there seems to be an almost equal distribution between 0700-1800 and 1900-0600 LST.

Analyses based on Passive Microwave satellite by Negri et al. (2000) show that the effect of local circulations associated with the topography and geography (coastlines, river valleys) of the region have a major impact on the diurnal rainfall distribution. They identified a maximum of rainfall during late afternoon around 1800 LST on a broad region south of the Amazon River, while along the eastern slopes of the Andes a morning maximum both at 0600 and 0900 LST was also identified. This is in broad agreement with the analyses based on geosynchronous satellite long wave infrared imagery GOES IR data by Garreaud \& Wallace (1997) and International Satellite Cloud Climatology Project-C2 phase (ISCCP-C2) data by Marengo (1995), and the gauge based rainfall analyses of Liebmann et al. (1998). 


\section{DATA AND METHODOLOGY}

\section{The TRMM-LBA and LBA-WET AMC rain gauge network}

During the 1999 TRMM/LBA field campaign, we used the 40 tipping buckets which provided rainfall with a 5minute resolution. The rain gauge networks were ordered on 4 clusters (referred hereafter at networks) along the Brazilian highway BR-364 from Cuiabá-Porto Velho, in the state of Rondônia, southwest Brazil, together with several other rain gauges nearby. The implementation and locations of the rainfall networks, other rainfall sites, and the TOGA and S-POL radar sites are shown in Table 1 and Fig. 1. We used the data from December 1998 to February 1999 from the 4 networks of pluviometers.

The pluviometers were previously calibrated in the factory and in the TRMM office. The rain gauge calibration consists in checking that each bucket can hold $8.868 \mathrm{ml}$ of water before it tips. One tip represents 0.01 inch of rain in that time interval. During this calibration processes this checking was performed at least 20 times for each bucket. At the end it was calculated the mean volume of water to each tip. If the mean value for each bucket is too different, the weighting screw in between the buckets was adjusted to obtain a better fitting, and then a checking was done until both tips have the same values of water.

During the field campaign the 40 rain gauges were already calibrated and presented the values specified by the factory, and later consistency and filtering checks were performed in order to avoid errors in the measurements. Those checks are based on the limitations that these buckets underestimate the low and high precipitation $(<0.1 \mathrm{~mm} / \mathrm{h}$ and $>100 \mathrm{~mm} / \mathrm{h}$ ). Therefore, if in one time interval (the temporal resolution was 5-10 seconds) there is more than 2 buckets, that count was flagged and only one bucket was counted. Later, a check is made to detect if there is rain in

Table 1 - The principal LBA-WET AMC and TRMM-LBA rainfall networks and other instrument sites (Fig. 1). Additional information includes the total of pluviometers on ach site, number of days with observation and accumulated rainfall. Period of observations was from December 221998 to February 281999.

\begin{tabular}{lccccc}
\hline \hline \multicolumn{1}{c}{ Name } & Lat. $\left({ }^{\circ} \mathrm{S}\right)$ & Lon. $\left({ }^{\circ} \mathrm{W}\right)$ & $\begin{array}{c}\text { Total } \\
\text { pluviom. }\end{array}$ & $\begin{array}{c}\text { Period } \\
(\text { days })\end{array}$ & $\begin{array}{c}\text { Total } \\
(\mathrm{mm})\end{array}$ \\
\hline Network 1 & $10.90^{\circ} \mathrm{S}$ & $61.85^{\circ} \mathrm{W}$ & 13 & 69 & 520 \\
Network 2 & $10.75^{\circ} \mathrm{S}$ & $62.15^{\circ} \mathrm{W}$ & 13 & 69 & 567 \\
Network 3 & $10.60^{\circ} \mathrm{S}$ & $62.35^{\circ} \mathrm{W}$ & 6 & 59 & 392 \\
Network 4 & $10.35^{\circ} \mathrm{S}$ & $62.55^{\circ} \mathrm{W}$ & 4 & 69 & 584 \\
TOGA & $10.75^{\circ} \mathrm{S}$ & $62.35^{\circ} \mathrm{W}$ & 1 & 44 & 305 \\
Rancho Grande & $10.30^{\circ} \mathrm{S}$ & $62.35^{\circ} \mathrm{W}$ & 1 & 44 & 291 \\
$\begin{array}{l}\text { ABRACOS Hill(Faz. } \\
\text { Nossa Senhora de }\end{array}$ & $10.75^{\circ} \mathrm{S}$ & $62.33^{\circ} \mathrm{W}$ & 1 & 60 & 790 \\
Aparecida) & & & & & \\
\hline \hline
\end{tabular}

at least 1 minute interval, to make sure we have a raining episode. As a second stage, a check is made for rain consistency. The rain gauge network was set to have at least 3 rain gauges closed to 100 meters of each other, and 10 in a $1-10 \mathrm{~km}$ radius. So in order to check if the gauges were measuring properly we did a correlation test among them (space and time). If only one gauge presented rain and the other nothing, these measurements were rejected. Finally, a new test is run to check if the measured rain among the rain gauges closed to each other were within $10 \%$ of the measurements. All these procedures are described in Anagnostou and Morales (2002).

\section{NCEP reanalysis and other data sets}

The daily $850 \mathrm{hPa}$ and 200-hPa circulations at 0000, 0600, 1200 and 1800 GMT from the National Centers for Environmental Prediction (NCEP) global reanalysis on the $2.5^{\circ} \times 2.5^{\circ}$ latitude/longitude grid (Kalnay et al. 1996) has been used in this study. Wind data was organized as "composites", that represent the two distinctly wind regimes noted in Rondônia during the field experiment in Rondônia, dominated by lower troposphere easterly and westerly flow.

Rainfall estimates were obtained from the Precipitation Estimation from Remotely Sensed Information using Artificial Neural Network PERSIANN System Satellite based tropical rainfall, available during 1999. The PERSIANN is an automated system that has been developed for the estimation of rainfall from GOES-IR imagery at a resolution of $0.25^{\circ} \times 0.25^{\circ}$ latitude-longitude (Sorooshian et al. 2000). The accuracy of this rainfall product is improved by using the instantaneous rain-rate estimates from the TRMM microwave imager.

The "composites" for both regimes were implemented from the 4-times-a-day NCEP and rainfall observations and using the westerly and easterly regime definition implemented by Rickenbach et al. (2002). They used surface-based radar data collected during the TRMM-LBA campaign to illustrate the distinctions in morphology of the precipitation and mesoscale convection. They identify that the westerly regime was associated with a moister troposphere and convection with weak electrification, while the easterly regime had a slightly drier troposphere and stronger electrified convection.

\section{RESULTS AND DISCUSSIONS}

From Table 1, the mean precipitation (mean of Networks 1-4) accumulated during the period December 221998 and February 28 1999 was $516 \mathrm{~mm}$. The mean of network 4 was 584 (the maximum), 


\section{ACTA AMAZONICA}

while the mean of network 3 was $392 \mathrm{~mm}$ (the minimum). In fact, network 3 showed a period with no rainfall registered (January 14-31 1999), when rainfall on the other networks was significant.

There was a general increase in heavy rain during two periods each of 7-10 days duration, centered on January 23, February 15-18, and February 24-15, due to isolated weather systems that affected the region on those days. Iintense localized convection was detected in January 23, while during February 15-18 and 24-25 two intense mesoscale systems affected the region. This accumulation for network 1 (nearby Ji-Paraná Airport) during summer season of 1998/99 was about $520 \mathrm{~mm}$ and showed to be much less than those during years of strong El Niño 1982/ $83(680 \mathrm{~mm})$ and La Niña 1988/89 $(910 \mathrm{~mm})$ for the same period December 22 - February 28. The signals of El Niño are not so clear in Southern Amazonia as compared to central or northern Amazonia (Marengo, 1992; Liebmann \& Marengo 2001).

\section{Synoptic conditions during the January- February 1999}

Weather reports and briefings of the January-February 1999 LBA-WET AMC campaign (CPTEC, 1999) describe the meteorological conditions and the large scale and synoptic systems present during the experiment. On January 25-27, the southern end of a very long and long-lived Amazon convective squall line produced precipitation in Porto Velho and Ji-Paraná during the night, with the very intense squall line affecting the region at approximately 1700-1800 LST, with abundant rain in most of the region from Rolim de Moura to Ariquemes. On January 29, the Northwest/ Southeast oriented frontal system was approaching Bolivia and southern Brazil, organizing convection along the air mass boundary. The period January 30-31 showed convection in Rondônia in the form of several lines with a Northwest/Southeast orientation. On February 1-5, coastal lines over the Northern coast of Brazil continued to be triggered and travel into Amazonia and a LLJ at $850 \mathrm{hPa}$ extended from Bolivia to southern Brazil that was associated to the development of a thermal surface low pressure system in northern Argentina-Paraguay, known as the Chaco Low. Most of the intense convection at afternoon and evening was in the Amazon and on the eastern slopes of the Andes. On February 7-9, several lines of convection were observed covering almost the whole state of Rondônia throughout the afternoon and the evening.

By February 10, a well-defined squall line developed in the coast of the state of Pará and started to penetrate inland. On February 12, convective activity over the state of Rondônia began to form between 1500 and 1600 GMT, and strengthened in many areas of the state throughout the afternoon, some of them producing strong thunderstorms. During the afternoon of February 14, four squall lines could be observed in Amazonia, all oriented Northwest-Southeast moving southwestward. Big cells developed and moved from Pará into Rondônia by late afternoon, producing heavy rain and strong thunderstorms. During the night of February 15 convective mesoscale line reached Rondônia at 1700 GMT, producing very heavy rain and lightning. The day after, a squall line that formed at the coast the day before with a Northwest-Southeast orientation, had moved inland. On February 20-21, a North-South convective line developed behind it traveling westward, and a nighttime storm to the southeast of Rondônia persisted and generated a northsouth line. By February 22 several deep convective systems were observed covering basically the whole State of Rondônia. On February 23, only a few isolated cells were seen in Rondônia without very deep cloud tops. During the night, a large mesoscale convective system was seen just to the southeast of Rondônia, embedded in the larger scale convergence line.

\section{Near-surface and upper-air wind regimes}

NCEP time series of zonal and meridional winds at a grid point near Ji-Parana are shown in Fig. 2. A significant feature of the zonal winds (Fig. 2b) was the alternation of

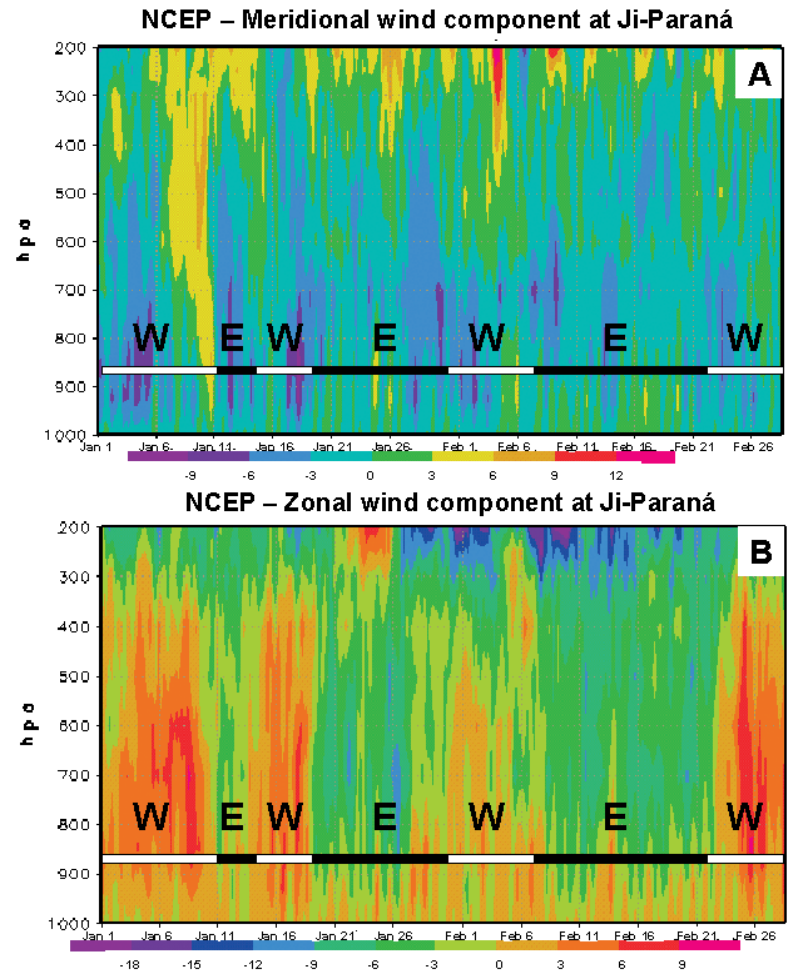

Figure 2 - Time series of meridional (a) and zonal (b) wind components derived from NCEP reanalysis for a grid point nearest to Ji-Paraná. Regime periods (westerly and easterly) are indicated by letters $\mathrm{E}$ and $\mathrm{W}$ and black and white bars, respectively. Units are in $\mathrm{m} / \mathrm{s}$, Color scale is shown on the lower side of each panel. 


\section{ACTA \\ AMAZONICA}

DIURNAL VARIABILITY OF RAINFALL IN SOUTHWEST AMAZONIA DURING THE LBA-TRMM FIELD CAMPAIGN OF THE AUSTRAL SUMMER OF 1999 periods of westerly shown in red-orange, and easterly shown in green-blue in the lower and middle troposphere, extending from surface to $\sim 300 \mathrm{hPa}$. Some of the periods of westerly winds lasted up to 10 days (January 1-10, January 29 -February 9) with a 20-day period in between. The easterly periods are longer than the westerly periods, and are more intense between 850 and $500 \mathrm{hPa}$. The meridional flow (Fig. 2a) shows, in general, northerly flow in the lower troposphere and southerly in the upper atmosphere. At the end of the first westerly period, there is a strong southerly flow (January 9-11), perhaps the strongest during the whole LBA WET AMC period. These wind regimes were very similar to the wind times series extracted from the NASA-DAO reanalyses over the area of the experiment and from the observational sounding data at the ABRACOS Hill (Rickenbach et al. 2002).

The "composites" of westerly and easterly regimes defined in Rickenbach et al. (2002) are here adopted, given the good agreement between NCEP reanalysis and observed winds. Those regimes are shown with black and white horizontal bars in Fig. 2. The only difference from Rickenbach's work is the additional westerly regime identified during January 1-11 using the NCEP reanalyses. This was a period when no sounding network was operational during the LBA WET AMC. Table 2 lists the westerly and easterly regime period, together with indications of SACZ and LLJ events. The three easterly events were coincident with non-SACZ episodes, and two of these episodes coincide with the presence of LLJ events. Furthermore, the westerly regime shows 2 SACZ episodes (one of them coinciding with a LLJ event), and one nonSACZ event linked to a LLJ episode. Therefore, there is not an apparent preference for LLJ episodes to occur during periods with or without SACZ, at least during JanuaryFebruary 1999.

Table 3 shows that there is good agreement between the easterly and westerly episodes determined from the NCEP reanalyses (Table 2 and Fig. 3) and those from upperair soundings at ABRACOS Hill. These episodes were determined using the $850-\mathrm{hPa}$ winds from the 2100 GMT upper air sounding at the ABRACOS Hill. Table 3 also shows

Table 2 - Episodes of westerly and easterly regimes during the January-February LBA WET-AMC 1999 campaign, as defined by NCEP reanalyses and by Rickenbach et al. (2002). Occurrence of LLJ episodes is from Marengo et al. (2003). The SACZ and non-SACZ description is based on Rickenbach et al. (2002).

\begin{tabular}{lcccc}
\hline \hline Regime & \multicolumn{1}{c}{ Period } & SACZ & LLJ \\
\hline Easterly & E1 & 11-14 January & Non-SACZ & \\
& E2 & 19-29 January & Non-SACZ & LLJ (18-21 January) \\
& E3 & 8-22 February & Non-SACZ & LLJ (12-13 February) \\
\hline Westerly & W1 & 1-11 January & & \\
& W2 & 14-19 January & SACZ & \\
& W3 & 29 January-8 February & Non-SACZ & LLJ (3-5 February) \\
& W4 & 22 February-1 March & SACZ & LLJ (21-24 February) \\
\hline \hline
\end{tabular}

rainfall at this site during those episodes and apparently there is not a tendency towards more or less rainfall during easterly periods, or with the intensity of rain and the magnitude of the zonal wind.

Table 3 - Episodes of westerly and easterly regimes during the January-February LBA WET-AMC 1999 campaign, as defined by the upper-air soundings at the ABRACOS Hill site. $U$ is the zonal wind component from the NCEP reanalysis.

\begin{tabular}{llcc}
\hline \hline Period & Regime & $\mathrm{U}(\mathrm{m} / \mathrm{s})$ & Precipitation $(\mathrm{mm})$ \\
\hline $10-11 / 1$ & Easterly & -3.3 & 4.4 \\
$12-18 / 1$ & Westerly & 3.2 & 5.7 \\
$19-29 / 1$ & Easterly & -4.5 & 18.6 \\
$30 / 1-2 / 2$ & Westerly & 1.4 & 21.0 \\
$3 / 2-21 / 2$ & Easterly & -3.5 & 15.5 \\
$22-28 / 2$ & Westerly & 3.1 & 22.7 \\
\hline \hline
\end{tabular}

\section{Diurnal cycle of rainfall}

The rain versus time diagrams (Fig. 3a-e) for networks 1-4, and a similar figure from Tota et al. (2000) for the ABRACOS Hill site show a large synoptic variability, reflected on the different rainfall peaks at different times during the December 12 1998February 28 1999, as well as periods of days with no rain in between rainy events. While some differences are observed in intense rainfall episodes (more frequent in networks 2 and 4 compared to networks 1 and 3), there is always a tendency for more frequent intense rainfall events around 1100-1600 LST and fewer at around 0100-0400 LST. In network 2, the rainfall maximum occurs around 1200 LST by the end of January, and changes to around 1700 LST by the end of February. Similarly, a secondary maximum around $0300 \mathrm{LST}$ is found in the middle of January and February. This suggests the interaction of different rainfall mechanisms in the area showing differences in timing of the maximum rainfall rate, and some isolated events, as described in Section 4.1. These isolated maxima (e.g. heavy rainfall at around 0700 LST on January 9 or at 0100-0300 LST on in 16-18 February) can dominate the mean diurnal cycle. The heavy rainfall event in networks 1 and 2 during January 9 was the only rainfall event at that hour of the day in the entire period, yet a peak is shown in Fig. 3a and $\mathrm{b}$ indicating an early maximum morning in the mean diurnal cycle.

Consequently, the mean diurnal cycle of rainfall shown in Figs. 4a-e exhibit the maximum intensity between 1300 and 1700 LST, which are consistent with the maximum found by Liebmann et al. (1998) in Ji-Parana between 1500 and 1700 LST using the ABRACOS data set, with diurnal composites from Rickenbach et al. (2002), and with some of the satellite based studies by Garreaud \& Wallace (1997); Negri et al. (2000); 


\section{ACTA AMAZONICA}
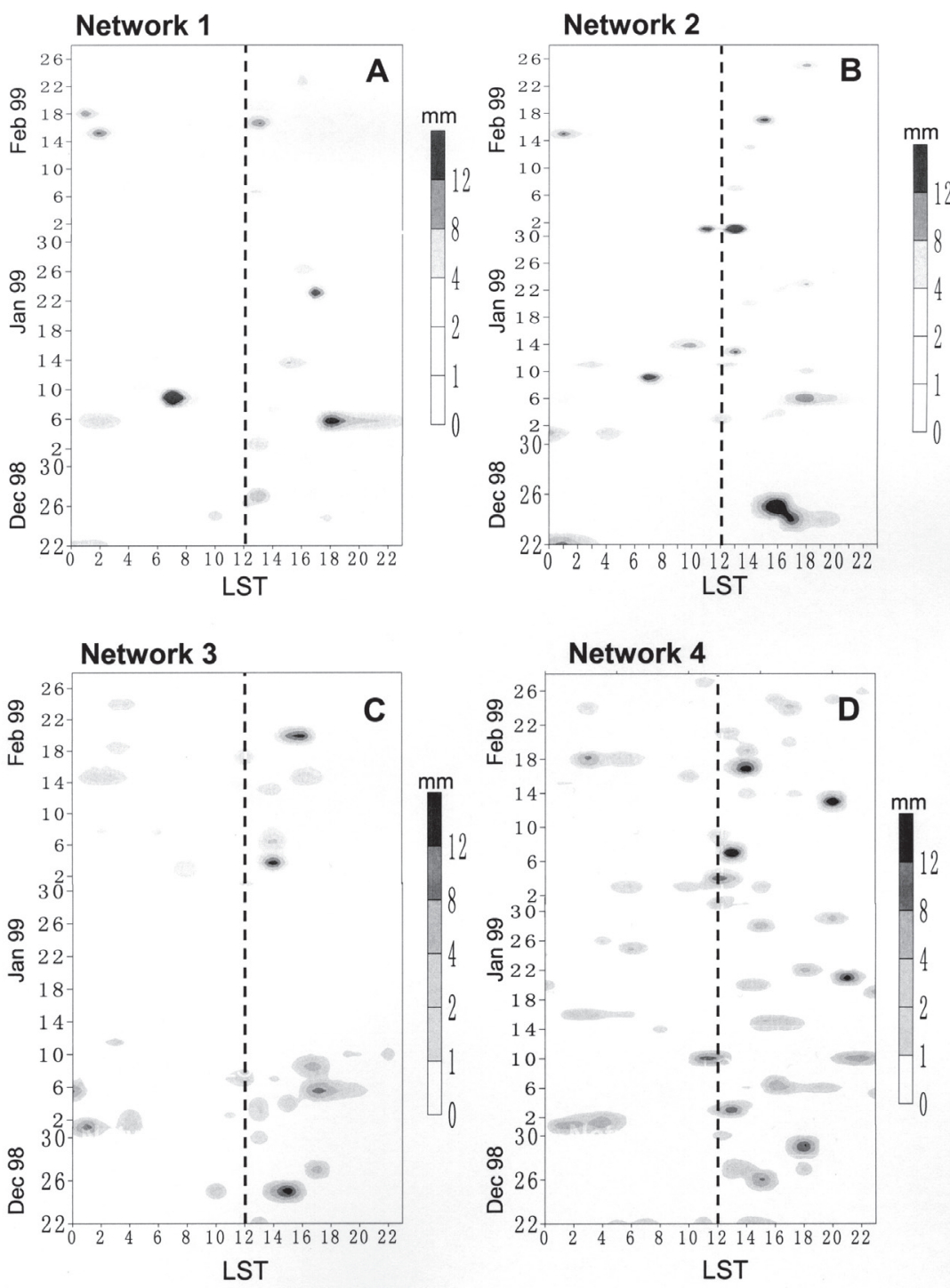

Figure 3 - Time-latitude diagrams of rainfall ( $\mathrm{mm} /$ hour) in networks $1,2,3,4$, for the period December 22 1998-February 28 1999. Time is in LST.

Imaoke \& Spencer (2000); and Lin et al. (2001). The smaller early morning peak (around 0000-0600 LST) occurred due to some weather events like squall lines and thunderstorms that developed at night, and moved from northeast to southwest, as deduced from the weather reports during those dates. Fig. 3 and 4 do not separate the fractions due to easterly or westerly regimes of circulation or due to convective processes of stratiform cloudiness.

An analysis of rainfall frequency for each hour might be a better indicator for describing the diurnal cycle. Network 1 (Fig. 5) shows $40 \%$ of events with less than $1 \mathrm{~mm} /$ day occurring between 0200 and 0900 LST, while $32 \%$ of rainfall events below $1 \mathrm{~mm} /$ day occurred between 1300 and 1900 LST. For daily precipitation events above $1 \mathrm{~mm} /$ day, the $24 \%$ occurring between
0100 and $0500 \mathrm{LST}$ contrasts with the $42 \%$ of frequency of events larger than $1 \mathrm{~mm} /$ day between 1200 and 1800 LST. Of those afternoon events, $45 \%$ show intensity larger than $5 \mathrm{~mm} /$ day. Similar behavior is observed for the other 3 networks.

These percentages, together with the diurnal variability of rainfall rates shown in Fig. 4 suggest more intense and/or frequent events of rainfall associated with strong convective activity in the afternoon due to strong surface heating and to the effects of organized large-scale convection associated to SACZ or to mesoscale convective systems, depending on the timing of the maximum rainfall. The larger frequencies of rainfall events less than 1 $\mathrm{mm}$ /day and the lower frequencies of more than 5 or $10 \mathrm{~mm} /$ day at morning indicate that rainfall at that time of the day show weaker and/or less frequent convective activity together with some stratiform cloudiness. However, some infrequent events accompanied by strong convective activity at night-early morning are also responsible for the second maximum of rainfall at this time of the day.

The weather conditions during January-February 1999 (CPTEC, 1999) show that some of the intense rainfall events responsible for the second maximum of rainfall between 0000 and 0800 LST were in fact due to some weather events different to those related to the afternoon maximum. From Figs. 4-5, as well as from similar figures for the ABRACOS Hill site (Tota et al. 2000); we observed more variability in the diurnal variability of rainfall, as compared to rainfall variability derived from the S-POL and TOGA radar data. This is probably due to the stratiform rain.

\section{Regional circulation and diurnal rainfall variability: Westerly versus easterly circulation regimes}

The classification of easterly and westerly regimes shown in Table 3, based on the analysis of Fig. 3 and on work by Rickenbach et al. (2002) also allows for the implementation of "composites" of mean diurnal cycle for rainfall representative of easterly and westerly regime periods (Fig. 6). The easterly diurnal composite shows a nocturnal peak $(\sim 0200$ LST $)$ almost 


\section{ACTA AMAZONICA}

DIURNAL VARIABILITY OF RAINFALL IN SOUTHWEST AMAZONIA DURING THE LBA-TRMM FIELD CAMPAIGN OF THE AUSTRAL SUMMER OF 1999
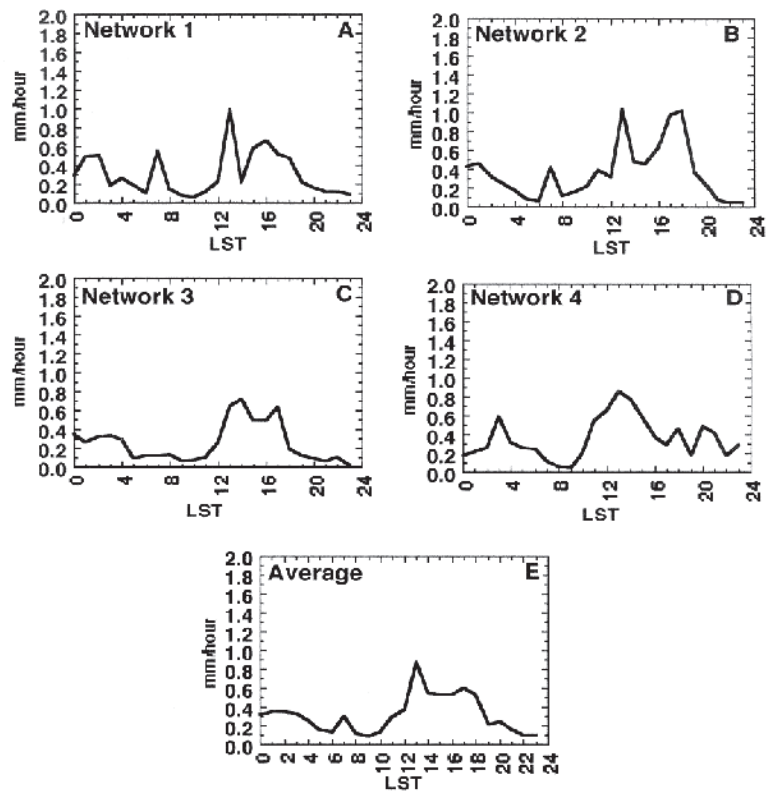

Figure 4 - Mean diurnal cycle rainfall ( $\mathrm{mm} /$ hour) in networks 1 , $2,3,4$ and the mean in the LBA-WET AMC and TRMM-LBA region. For location of sites refer to Fig. 1. For information on rainfall statistics in each network, refer to Table 2. Time is in Local Standard Time (LST). Scale is shown on the right side.

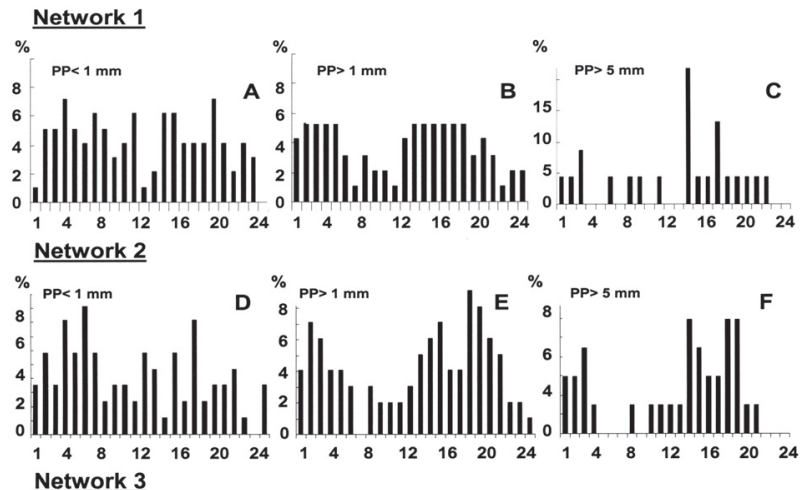
twork

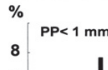

\begin{tabular}{l|l|}
8 \\
6 \\
4 \\
2 \\
0
\end{tabular}

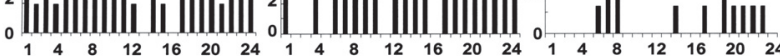
Network 4

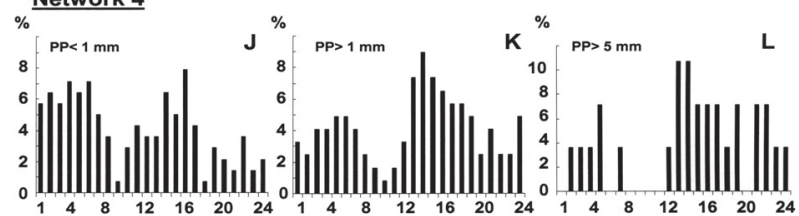

Figure 5 - Hourly frequency distribution of rainfall in the 4 networks according to intensity: precipitation less than $1 \mathrm{~mm} / \mathrm{day}$ (a, d, g, j), precipitation above $1 \mathrm{~mm} /$ day (b, e, h., k), precipitation above $5 \mathrm{~mm} /$ day (c, f, I, l). Time is in Local Standard Time (LST). Frequency (\%) is shown on the right side. as large as the afternoon peak (1300-1500 LST). Studies by the Colorado State University (CSU) Radar Meteorology Group (Cifelli et al. 2002) have shown that the TOGA radar observations do not show anything like this, showing instead a very weak nocturnal maximum independent of the regime. The nocturnal maximum probably comes from a few nocturnal squall lines, as observed during February 15-18 and 24-25.

The diurnal amplitude from the gauge westerly composite is somewhat smaller than for the gauge easterly component (Fig. 6). A large peak in the westerly regime was detected during the afternoon, and followed by a small peak between 2100-2200 LST. The westerly regime mean does not show the large peak detected at late night-early morning during days with easterly regime. This peak in the easterly regime at around 0200-0300 LST is related to convective activity linked to mesoscale convective complexes as well as to instability lines. On the other hand, the maximum on the easterly composite during $1200-1400$ LST is related to mid-afternoon convective activity while the afternoon peak is indicative of the timing of the strongest convective activity, the early morning is also in part due to some limited convective activity at night. In fact, the difference in rain intensity between westerly and easterly wind regimes was associated with the convective portion of the rainfall at mid afternoon.

The larger intensity of the peaks in the easterly regime, as compared to the westerly regime, is consistent with Betts et al. (2002), who found that the easterly regime has stronger electrified convection with large vertical development, while the westerly regime exhibits convection with weak vertical development and weak electrification. Analysis by Cifelli et al. (2002) suggests that the rainfall weighted daily mean shows a $73 \%$ fraction due to convection and $27 \%$ due to stratiform contribution, with the easterly regime showing a $80 \%$ of convective fraction (and 20\% stratiform) and the westerly regime showing $62 \%$ of convective fraction (and 28\% stratiform).

Composites of NCEP winds at 850 and $200 \mathrm{hPa}$ and PERSIANN rainfall for the westerly and easterly regime composites listed in Table 2 are shown in Fig. 7. For the westerly

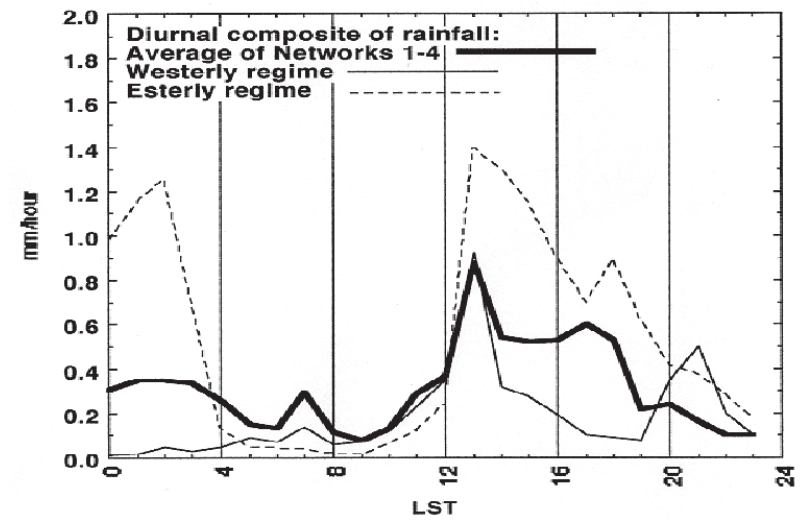

Figure 6 - Mean diurnal cycle of rainfall for networks 1-4 (full thick line), average of the westerly regime (thin full line), and easterly regime (thin broken line). Values are in $\mathrm{mm}$ /hour and time is LST. 


\section{ACTA AMAZONICA}

regime composite (Fig. $7 \mathrm{~b}$ ), between the equator and $6^{\mathrm{c} S}$, the near-surface northeast trades prevail over central Amazonia, and south of $8^{\mathrm{c}} \mathrm{S}$ the winds are deflected by the Andes, acquiring a northwesterly component from the Andes foothills to the state of Mato Grosso, approximately $1300 \mathrm{~km}$ to the east of the Andes, with an axis extending from western Amazonia all the way to Bolivia, Paraguay and southern Brazil. Two LLJ and SACZ episodes occurred during westerly regime events and the LLJs serve as moisture corridor from the central Amazonia to the SACZ, as shown by the rainfall maps (Fig. 7c).

At upper levels (Fig. 7b), the Bolivian Anticyclone is located around $20{ }^{\mathrm{c} S} 64^{\mathrm{c}} \mathrm{W}$, producing southeasterly winds all over Rondônia and central Amazonia. When compared to the upperlevel flow of the easterly regime composite (Fig. 7b), the center of the anticyclone is displaced to the east by approximately 5 degrees, and the upper level trough over Northeast Brazil is here more intense and defined, as compared to the westerly regime composite, due to the intensification of the upper-level anticyclonic circulation. Near surface, the easterly regime (Fig. 7e) shows a northwesterly flow restricted to the foothills of the
Andes in Bolivia with an axis extending from northern Bolivia to Paraguay, and more meridional that the axis in the westerly case. Over Rondônia, the flow is more of a northeasterly component.

The mean rainfall during the westerly regime (Fig. 7c) shows abundant rainfall on the exit region of the LLJ and extending into the southern Brazil region to the Atlantic Ocean, along the SACZ. On the easterly regime (Fig. 7f) this LLJ was not present, suggesting that this regime did not exhibit a moisture transport from the tropics extending into the subtropics, with the absence of a SACZ and LLJ as derived from the mean composites.

\section{FINAL REMARKS}

The TRMM-LBA field campaign was held during the austral summer of 1999 in southwestern Amazonia. Among the major objectives there was the identification and description of the diurnal variability of rainfall in the region, associated with the different rain producing weather systems that occurred during the January-February 1999 season. By using a network of 40 rain gauges implemented in the state

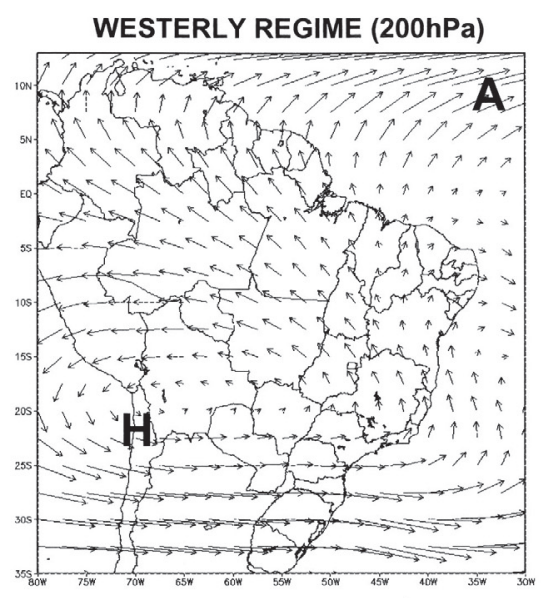

WESTERLY REGIME (200hPa)

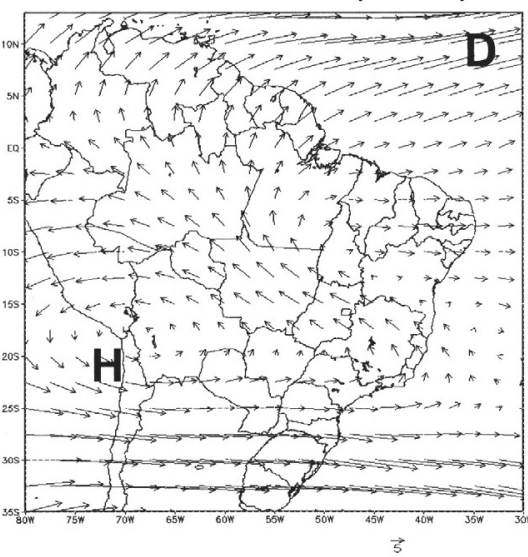

WESTERLY REGIME (850hPa)

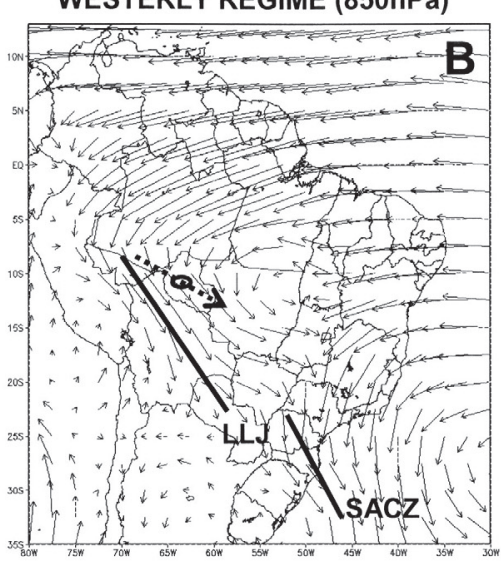

WESTERLY REGIME (850hPa)

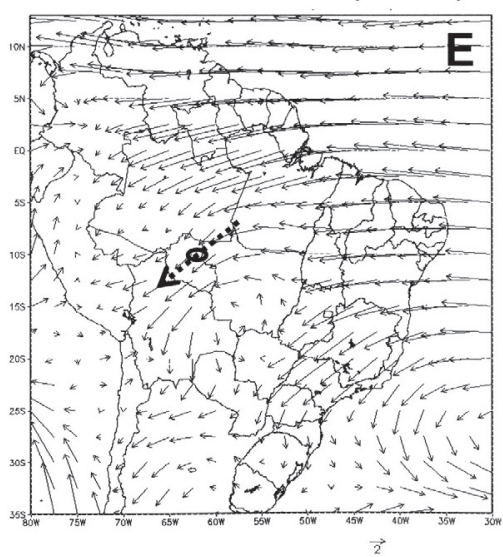

WESTERLY REGIME

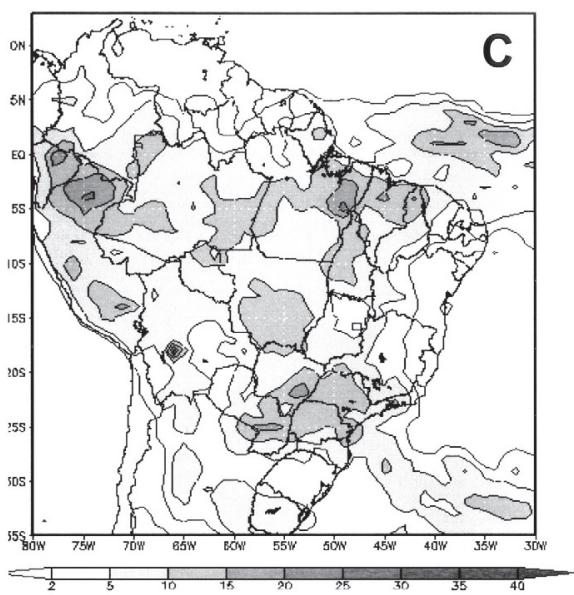

WESTERLY REGIME

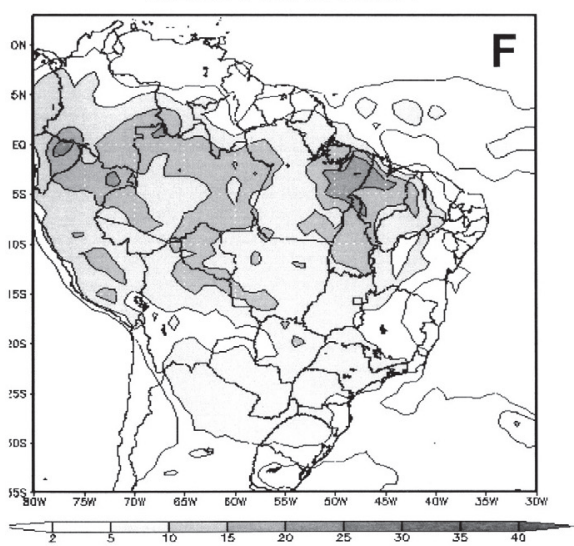

Figure 7 - Composites of 200-hPa, 850-hPa circulations and rainfall for westerly and easterly regimes, from NCEP reanalysis (a, b, d, e), and PERSSIAN rainfall (c, f). See Table 3 for the dates considered for each regime 


\section{ACTA \\ AMAZONICA}

DIURNAL VARIABILITY OF RAINFALL IN SOUTHWEST AMAZONIA DURING

THE LBA-TRMM FIELD CAMPAIGN OF THE AUSTRAL SUMMER OF 1999 of Rondônia, it was possible to identify several episodes of rainfall and to identify the diurnal cycle of these rainfall events, some of them related to different weather regimes.

Diurnal variability of rainfall shows an average maximum in the afternoon, with some lower peaks around 0700 and 1600 LST due to some strong rainfall events during JanuaryFebruary 1999. In all networks, there is a relatively larger frequency of events with precipitation lower than $1 \mathrm{~mm} /$ day at early morning than in the afternoon, while for events with precipitation events more than 1 and $5 \mathrm{~mm}$ /day, the maximum occur at afternoon. This suggests the presence of convective development and stratiform rain events, or both, according to the large-scale circulation weather systems affecting the region of the experiment.

Rainfall episodes were characterized by regimes of lowlevel easterly and westerly winds in the context of the largescale circulation. The westerly regime is related to an enhanced, while the easterly regime is related to easterly propagating systems (e.g. squall-lines) mostly during nighttime, with a possible suppression of the SACZ.

The diurnal variability of rainfall shows that during the westerly surface wind regime, rainfall shows a characteristic maximum at late afternoon followed by a relatively weaker second maximum at early evening (2100 LST). The easterly regime composite shows an early morning maximum followed by an even stronger maximum in the early afternoon. Weather reports and circulation features typical of each regime indicate that the westerly regime were characterized by baroclinic waves extending into central Amazonia, showing enhanced moisture transport from Amazonia to southern Brazil along the east of the Andes via the LLJ, or leading to the development of SACZ events. Some westerly events exhibited a well developed LLJ during SACZ episodes.

The easterly regime exhibited frontal systems that did not reach central Amazonia and the moisture transport from the deep tropics to subtropical South America was relatively weaker as compared to the westerly regime. Over Rondônia, there is little difference in rainfall during both regimes. However, rainfall in central and eastern Amazonia is more abundant during the easterly regime, while the Atlantic ITCZ appears to be wider and stronger producing more rainfall over Northeast Brazil during the westerly regime, together with the stronger SACZ.

From the mean diurnal cycle of the 4 networks and the analyses of the large-scale circulation and rainfall over the TRMM-LBA region, we observed that the diurnal cycle of rainfall during easterly regime shows the development of large-scale circulation and convection that favor more rainfall and strong convective development in the afternoon, while on the westerly regime an afternoon peak is also observed even though almost $50 \%$ weaker than on the easterly regime, suggesting that this peak could be associated more to large scale stratiform clouds coexisting with convective clouds.

The early morning maximum of rainfall during the easterly regime indicates a possible role played by re-developing stratiform cloud at night. However, it is also possible that this maximum could be somewhat overestimated due to the small sample size (70 days of data). During the westerly regime, enhanced convection due to intensified mesoscale convective systems and rain over the La Plata River basin and the SACZ contrasts with less rainfall on the TRMM-LBA region, while the opposite occurs during the easterly regime (Herdies et al. 2002).

In summary, diurnal variations of rainfall associated with convective and stratiform clouds are different from both easterly and westerly regimes. Convective rainfall exhibits a maximum in the afternoon; while the stratiform rainfall tends to have a maximum at early morning, together with some scatter shallow clouds. In the easterly regime, stratiform clouds may have also been observed in the afternoon coexisting with convective clouds, producing some rainfall on the region. Some other studies based on TRMM data for Amazonia (See sections 2.2 and 3.1) have identified shallow scatter clouds in the early morning, the heaviest precipitation (many from deep convective clouds) during the afternoon, and between late night and early morning radiative cooling produce a redevelopment of stratiform clouds that produce a small rainfall peak at this time. From our analyses, we suggest that the early morning maximum during the easterly regime may be due to the presence of 2 or 3 instability lines that can produce stratus clouds.

The study is based on a-three month high temporal resolution rainfall information and should be considered as representative of the specific summer period of 1999, and does not represent a climatology. At the present, we are performing similar analyses for the data generated during the August-October field campaign of LBA DRY-TO WET in southeast Amazonia during the dry season-transition to the wet season of 2002, and during the SALLJEX-Brasil field experiment during the December 2002-February 2003 period.

\section{ACKNOWLEDGEMENTS}

This work was funded by FAPESP grant 1999/05106-2 for the LBA-WET AMC field campaign and FAPESP grants 01/138161 and 01/06908-7. Paulo Gustavo Cervantes Dias was partially funded by a FAPESP student grant. Additional thanks are to Michael Douglas from NSSL/NOAA, and the TRMM scientists E. Zipser W. Petersen, T. Rickenbach, E. Williams, P. Silva Dias, M. Silva Dias, J. Tota and colleagues from the University of Utah, Colorado State University, NASA-GSFC TRMM Office, CPTEC, University of São Paulo for helpful scientific discussions. Thanks are also due to Eduardo Lacerda from INCRA in Ji-Paraná and Jorge Martins Nogueira from CPTEC for the maintenance, operation and data collection of the rain gauge networks.

\section{LITERATURE CITED}

Anagnostou, E. N.: Morales, C.A 2002: Rainfall estimation from TOGA radar observations during LBA field campaign, $J$. Geophys Res., 107: 66-91.

Arkin, P.; Meisner, B. N. 1987. The relationship between largescale convective rainfall and cloud over western hemisphere during 1982-84. Mon Wea Rev., 115: 51-74. 


\section{ACTA AMAZONICA}

Betts, A. K.; Fuentes, J. D.; Garstang, M. Ball. J. H. 2002. Surface diurnal cycle and boundary layer structure over Rondonia during the rainy season. J. Geophys. Res., 107:129-140.

Cifelli, R.; Petersen, W.A.; Carey, L.D.; Rutledge, S.A. 2002. Radar Observations of the Kinematic, Microphysical, and Precipitation Characteristics of Two MCSs in TRMM-LBA. In press.J. Geophys. Res. 107: 44/1 -44/13.

CPTEC, 1999. Climanalise, 14: 1-2. (www.cptec.inpe.br/products/ climanalise).

Ferreira da Costa, R.; Feitosa, J.R.P.; Fisch, G. F.; Souza, S.S.; Nobre, C.A. 1998. Variabilidade diária da precipitação em regiões de floresta e pastagem na Amazônia. Acta Amazônica, 28: 395-408.

Figueroa, S.N.; Nobre, C.A 1990. Precipitation distribution over central and western tropical South America. Climanálise, 6:36-40.

Fisch, G. F.; Marengo, J. A.; Nobre, C. A. 1998. Uma revisão geral sobre o Clima da Amazônia. Acta Amazonica, 28: 101-126.

Garreaud, R.; Wallace, J. M. 1997. The diurnal march of convective cloudiness over the Americas. Mon Wea. Rev., 125: 3157-3171.

Gash, J. H; Nobre C. A.; Roberts J.; Victoria, R. L. 1996. An overview of ABRACOS. In Amazon deforestation and climate. J. Gash, C. Nobre, J. Roberts and R. L. Eds. John Wiley and Sons, Chichester, New York, Brisbane, Toronto and Singapore, 1-14 pp.

Gash, J.H.C.; Nobre, C.A. 1997. Climatic effects of Amazonian deforestation: some results from ABRACOS. Bull Am Met Soc., 78: 823 - 830,

Greco, S.; Swap, R.; Garstang, M.; Ulanski, S.; Shipham, M.; Harris, R. C.; Talbot, R.; Andreae, M. O.; Artaxo, P. 1990. Rainfall and surface kinematics conditions over Central Amazonia during ABLE 2B. J. Geophys Res., 95: 17001-17014.

Herdies, D.L.; da Silva, A.; Silva Dias, M.A.; Ferreira, R. N. 2002. Moisture budget of the bimodal pattern of the summer circulation over South America.J.Geophys.Res. 107:8075-8084.

Imaoka, K.; Spencer, R. W. 2000. Diurnal variation of precipitation over the tropical oceans observed by TRMM/TMI combined with SSM/I. J. Climate, 13: 4149-4158.

Kalnay, E.; Kanamitsu, M.; Kistler, R.; Collins, M.; Deaven, W.; Gandin, D.; Iredell, L.; Saha, M.; White, S. G; Woollen, T.; Zhu, J.; Chelliah, M.; Y., Ebisuzaki; Higgins, W.; Janowiak, J.; Mo, K. C.; Ropelewski, C.; Wang, J.; Leetma, A.; Reynolds, R.; Jenne R.; Joseph, D. 1996. The NCEP/NCAR 40-Year Reanalyses Project. Bull. Am. Met. Soc., 77: 437-471.

Liebmann, B.; Marengo, J.; Glick, J.; Wainer, I.; Kousky, V.; Massambani, O. 1998. Comparison of Long wave radiation, divergence and rainfall in the Amazon basin on subseasonal scales, J. of Climate, 7: 2898-2909.

Liebmann, B.; Kiladis, G.; Marengo, J. A.; Ambrizzi, T.; Glick, J. 1999. Submonthly convective variability over South America and the South Atlantic Convergence Zone, J. Climate, 12: 1877-1891.

Liebmann, B.; Marengo, J. A.; 2001. Interannual Variability of the rainy season and rainfall in the Brazilian Amazon Basin, $J$. Climate, 14: 4308-4318.

Lin, X. L.; Randall, D. A.; Fowler, L. D. 2000. Diurnal variability of the hydrological cycle and radiative fluxes: Comparisons between observations and a GCM.J. Climate, 13: 4159-4179.
Marengo, J. A. 1992. Interannual variability of surface climate in the Amazon Basin. Int. J. Climatol., 12: 853-863.

Marengo, J. A. 1995. Interannual variability of deep convection over the tropical South American sector as deduced from ISCCP C2 data. Int. J. Climatol., 15: 995-1010.

Marengo, J. A.; Douglas, M.; Silva Dias, P. 2002. The South American Low-Level Jet East of the Andes during the LBA-TRMM and LBA-WET AMC campaign of January-April 1999. J. Geophys. Res., 107: 47/1-47/11

Marengo, J. A.; Nobre, C.A. 2001. The Hydroclimatological framework in Amazonia. In Biogeochemistry of Amazonia, Richey, J., McClaine, M., Victoria, R., Eds., pp. 17-42.

Molion, L. C. B. 1987. On the dynamic climatology of the Amazon Basin and associated rain-producing mechanisms. In Geophysiology of Amazonia, R. E. Dickinson Ed., John Wiley and Sons, 391-407.

Nesbitt, S. W.; Zipser, E. J.; Cecil, D. J. 2000. A census of precipitation features in the tropics using TRMM: Radar, Ice scattering, and lightning observations. J. Climate, 124: 4087-4106.

Negri, A.; Anagnostou, E.; Adler, R. 2000. A 10-yr climatology of Amazonian rainfall derived from Passive Microwave Satellite Observations. J. Applied. Met., 39: 42-56.

Nogues-Paegle, J.; Mo, K. 1997. Alternating wet and dry conditions over South American during summer, Mon Wea Rev., 125: 279-291.

Rao, V. B.; Hada, K. 1990. Characteristics of rainfall over Brazil. Annual variations and connections with the Southern Oscillation. Theor. Appl. Climatol., 42:81-91.

Rickenbach, T.; Nieto Ferreira, R.; Silva Dias, M. A. F.; Halverson, J. 2002. Modulation of convection in the western Amazon Basin by extratropical stationary fronts., J. Geophys Res., 107: 7/1 - 7/13.

Seluchi, M.; Marengo, J. A. 2000. Tropical-Mid Latitude Exchange of Air Masses during summer and winter in South America: Climatic aspects and extreme events, Int. J. Climatol, 20: 1167-1190.

Shin, K. S.; North, G.; Ahn, Y.; Arkin, P. 1990. Time scales and variability of area-averaged tropical oceanic rainfall. Mon Wea Rev., 118: 1507-1516.

Silva Dias, P.; Bonatti, J. P.; Kousky, V. E. 1987. Diurnally forced tropical tropospheric circulation over South America. Mon Wea Rev., 115: 1465-1478.

Silva Dias, M.; Silva Dias, P.; Rutledge, S.; Lima, M. A.; Gomes, A.; Antonio, M.; Fisch, G.; Rocha, H. 2002. Case study of multiple convective lines during the WET AMC/LBA and TRMM/Brazil. In Pess, J. Geophys. Res. 107: 39.1 - 39.20.

Sorooshian, S.; Hsu K.; Gao X.; Gupta V.; Imam B.; Braithwaite D. 2000. Evaluation of PERSIANN System satellite-based estimates of tropical rain. Bull Am. Met Soc, 81: 2035-2046.

Tota, J.; Fisch, G.; Oliveira, P.J.; Fuentes, J.D.; Siegler, J. 2000. Variabilidade da precipitação em área de pastagem durante o experimento LBA/TRMM. Acta Amazônica, 30: 305-318.

\footnotetext{
RECEBIDO EM: 18/12/2002
}

ACEITO EM: 19/11/2003 
